\title{
Secreted Frizzled-Related Protein 5
}

National Cancer Institute

\section{Source}

National Cancer Institute. Secreted Frizzled-Related Protein 5. NCI Thesaurus. Code C105006.

Secreted frizzled-related protein 5 (317 aa, $\sim 36 \mathrm{kDa}$ ) is encoded by the human SFRP5 gene. This protein may play a role in determining the polarity of photoreceptor cells in the retina. 